\title{
People and Things on the Move: Domestic Material Culture, Poverty and Mobility in Victorian London
}

\author{
Alastair Owens ${ }^{1} \cdot$ Nigel Jeffries $^{2}$ \\ (C) The Author(s) 2016. This article is published with open access at Springerlink.com
}

\begin{abstract}
The development of what Mayne and Lawrence (Urban History 26: 325-48, 1999) termed "ethnographic" approaches to studying nineteenth-century households and urban communities has gathered momentum in recent years. As such research agendas have taken hold and been applied to new contexts, so critiques, methodological developments, and new intellectual and theoretical currents, have provided opportunities to enhance and develop approaches. This article contributes to this on-going process. Drawing upon household archaeological research on Limehouse, a poor neighborhood in Victorian London, and inspired by the theoretical insights provided by the "new mobilities paradigm," it aims to place "mobility" as a central and enabling intellectual framework for understanding the relationships between people, place, and poverty. Poor communities in nineteenth-century cities were undeniably mobile and transient. Historians and archaeologists have often regarded this mobility as an obstacle to studying everyday life in such contexts. However, examining temporal routines and geographical movements across a variety of time frames and geographical scales, this article argues that mobility is actually key to understanding urban life and an important mechanism for interpreting the fragmented material and documentary traces left by poor households in the nineteenth-century metropolis.
\end{abstract}

Keywords Households $\cdot$ Mobility $\cdot$ Material culture $\cdot$ London $\cdot$ Nineteenth century

Alastair Owens

a.j.owens@qmul.ac.uk

Nigel Jeffries

njeffries@mola.org

1 School of Geography, Queen Mary University of London, Mile End Road, London E1 4NS, UK

2 MOLA (Museum of London Archaeology), Mortimer Wheeler House, 46 Eagle Wharf Road, London N1 7ED, UK 


\section{Introduction}

Almost two decades ago historian Alan Mayne and archaeologist Susan Lawrence published an essay in the journal Urban History announcing a "new urban research agenda" (Mayne and Lawrence 1999). Drawing from their collaborative work on nineteenth-century Melbourne in Australia, they challenged scholars to develop "ethnographic" approaches to studying cities through the innovative bringing together of archaeological and other historical evidence in order to build a richer understanding the complexities of everyday urban life. Working mainly at the scale of individual households, streets or neighborhoods, the "ethnographic" methods they advocated involved establishing a matrix of material and documentary evidence - from traces of building structures and collections of artefacts retrieved from particular households, to census lists of inhabitants, records of local businesses and institutions, legal documents, descriptive accounts of the neighborhoods, and other historical sources that "thicken" understanding of context. This material and documentary evidence was then to be brought into an open "dialogue" from which scholars could attempt to build meanings and interpretations. With a strong revisionist agenda, advocates promised that these approaches could challenge and "unravel conventional historical understandings," being attentive to but not constrained by existing historical narratives and being informed but not driven by theory, in order to cast light on the "actualities" of life in cities (Mayne and Murray 2001a, p. 1). Like similar studies focused on nineteenth-century households and communities in North American cities, this kind of historical archaeology has been most fruitfully applied to researching poorer urban neighborhoods where there has been an effort to reach beyond demonizing, bourgeois-driven representations of such localities to provide an account "that comes closer to an insider's view," recovering the complex diversity of peoples' struggles and experiences that were part of their day-to-day existence (Yamin 2001a p. 2; see, more broadly, the essays in: Mayne and Murray 2001b; Yamin 2001b, 2002; Gadsby 2011; Spencer-Wood and Matthews 2011). Historians too have advocated the value of micro-historical perspectives and the study of everyday life in order to recover the agency of marginalized peoples and the complexity of their lived experiences (Port 2015).

Swept along by a wider intellectual enthusiasm for the study of the "material" dimensions to social life and an interest in the "more-than-representational" registers of human experience, this body of scholarship has matured into a substantial and important field, and has resulted in greater collaboration between historians, archaeologists, and "thing theorists," alongside the initiation of other cross-disciplinary dialogues (see Hicks and Beaudry 2010). While much of the best of this research remains associated with scholars working in Australia and the United States, mounting interest in transnational archaeology as well as an increasing appreciation of the need for conservation of what the British would call the 'post-medieval' archaeological record in other contexts, has meant that historical-ethnographic accounts of urban localities are now being written for other countries. This has enabled opportunities for comparative study across different territories as well as consideration of the way that global (capitalist) processes increasingly shaped urban experiences in a range of settings (Murray and Crook 2005). In the United Kingdom - the focus of this article engagement with these agendas has been slower to emerge, though some recent 
projects have begun to make use of the rich resources available to do so (see, for example, Rimmer et al.'s (2011) special collection of essays in the International Journal of Historical Archaeology on archaeologies of poverty in the Hungate district of York; Jarrett (2013) on Victorian Derby; and Jeffries et al. (2009); and Owens et al. (2010a, b) on nineteenth-century London).

A maturing field is one that should be open to critique. Translating approaches pioneered elsewhere into a new context provides an opportunity to take stock of strengths and weaknesses as well as to reflect on challenges and issues that need to be addressed. Working in a different setting also raises new questions and problems while suggesting fresh ideas and refined approaches. Historical archaeologists of nineteenth-century cities have actively sought to self-critique their field, from exploring broad epistemological issues about the ambiguities of interpreting different kinds of historical evidence (Mayne 2007, 2008), to examining more specific methodological questions about how to assess the quality of surviving material artefacts (Crook 2011), or experimenting with new and creative ways of writing up findings (Yamin 2001c). Certain areas of debate and critique have taken on a more overtly political character, such as those that concern the extent to which research on poor nineteenth-century households and urban communities has a tendency to replace an historical narrative of oppression and class-based inequality with one based around tales of individual tenacity and resilience, where needy individuals ultimately triumph against adversity (Orser 2011; Symonds 2011a, b). While such approaches might rescue the poor from the willfully distorting gaze of nineteenth-century writers and social reformers, critics argue that they are too easily re-cast as self-improving consumers - a perspective that sits all too comfortably with the neo-liberal values and mind-sets of twenty-first century scholars ignoring the structural constraints that confined many to a life of poverty (Symonds 2011a; see also Matthews 2011). This article seeks to engage with some of these debates and contribute to the on-going evolution and critique of the field. It does so by focusing on an issue that raises both conceptual and methodological challenges for historical archaeologists of nineteenth-century cities: the mobility and restlessness of urban life. It seeks to address the question of what it means to undertake historicalarchaeological research in contexts where people and their things seem constantly to be on the move.

\section{Mobility and the Historical Archaeology of Nineteenth-Century Cities: Problems and Opportunities}

Drawing upon her work on New York, Diana Wall (2009) recently reflected on some of the methodological difficulties and challenges of undertaking household archaeology in nineteenth-century urban settings. Among the more significant of these, is the issue of whether it is possible to link the rich and diverse artefact assemblages that form a key element of the evidence matrix of historical archaeology, often found in redundant privies, middens, soakaways and similar features, with the people who lived in adjacent houses and streets. Is it always possible to identify who might have occupied, owned or used the structures that have been unearthed or objects that have been excavated? In some of the best examples of the historical archaeology of nineteenth-century cities scholars have often succeeded in doing this. Adrian and Mary Praetzellis' (2004) work 
on West Oakland in California offers a very good example of where it has been possible to narrate an insightful history of people's experiences and aspirations by linking specific objects and assemblages to known individuals, families and households, folding different kinds of evidence into a rich interpretative mix. But when it is not possible to establish definite connections between known people and archaeological artefacts, the ability to employ these approaches and meaningfully interpret material remains - to ethnographically understand their significance as objects that featured in the everyday domestic routines of individuals - would seem to be limited. As Wall (2009) pointed out, establishing the ownership and thereby contextualizing the use of objects can rarely be done with certainty, especially among those urban dwellers whose socio-economic position was less comfortable than the families studied by the Praetzellises. In the context of poorer, anonymous and more transient urban communities, making connections between people and objects frequently involves methodological leaps of faith and requires acceptance of a level of ambiguity in relation to the arguments and interpretations that can be advanced.

The problem is that within nineteenth-century cities like Melbourne, New York, or London people and their things seem constantly to have been on the move. In seeking to apply some of the 'ethnographic' perspectives advocated by Australasian and North American household archaeologists to the study of urban life in Victorian London, our own research faced this challenge. Focused on a series of households in Limehouse, in London's East End - a poor riverside district close to the city's docks - it was immediately clear that we were dealing with a transient community. Knowing who might have lived in a particular household at specific time was difficult to determine because individuals shifted address frequently and often sought refuge at particular locations only temporarily. They moved in and out of the city and came and went from Limehouse on a regular basis. In daily life itself people's movements crisscrossed the city as they engaged in a range of social and economic routines. As both contemporaries and subsequent theorists of urban life have observed, cities never stand still; restlessness and fluidity are key characteristics of modern urbanism (see Dennis 2008). For historical archaeologists, however, this mobility is a problem, becoming an obstacle to undertaking household archaeology, particularly in the context of poor neighborhoods. If connecting people with objects lies at the crux of the methodological and interpretative framework of the ethnographic ambitions of urban household archaeology, the inability to fully capture the complexity of people's movements so that the question of who might have owned and used artefacts can be answered, would seem to represent a significant weakness.

In the present article we want to tackle this issue head on. Rather than seeing the mobility of people and things as a problem for undertaking domestic archaeology in poor nineteenth-century urban neighborhoods, we want to place mobility as a central focus of the research and recast it as an enabling analytical perspective. What does it mean for historical domestic archaeology if we think about people and things as being constantly on the move? We would like to suggest that an attentiveness to movement provides opportunities for re-invigorating "ethnographic" approaches to studying nineteenth-century cities, unlocking understanding of and raising fresh questions about urban life. What can the exploration of mobility suggest to us about the routines and rituals that were part of everyday social practices? What do peoples' frequent moves and the material traces that follow them or get left behind, both within and beyond 
urban neighborhoods, tell us about creative responses to economic and social change? To what extent does a focus on the mobility of people and things enable us to begin to rethink ideas of ownership and use of material goods and associated acts of homemaking? Can a focus on mobility help us to address some of James Symonds' (2011a) recently articulated concerns about household archaeologies of poor neighborhoods in nineteenth-century cities - that there is too great an emphasis on individual or household experiences as opposed to collective struggles; or that the focus on homemaking and domestic objects and associated narratives of consumption, replicates a middleclass gaze upon the past that is barely more critical than contemporary bourgeois representations of the urban poor?

In emphasizing movement our arguments speak to wider intellectual debates within the humanities and social sciences that have sought to underline the importance of mobility in understanding social life. According to Hannam et al. (2006, p. 1), for example, "a mobility turn is spreading into and transforming the social sciences, not only placing new issues on the table, but also transcending disciplinary boundaries and putting into question the fundamental 'territorial' and 'sedentary' precepts of twentiethcentury social science." Much of the impetus for the new theorizing and methodological innovation associated with this field comes from a concern to understand the unprecedented levels of travel and migration that are a feature of the contemporary world - a world where "asylum seekers, international students, terrorists, members of diasporas, holidaymakers, business people, sports stars, refugees, backpackers, commuters, the early retired, young mobile professionals, prostitutes, armed forces ... and many others, fill the world's airports, buses, ships and trains" (Sheller and Urry 2006, p. 207). There is also an interest in the new forms of virtual and imaginative travel that have been enabled by the internet, mobile-telephonic and other technologies. Finally, and of particular relevance for this article, there has been a concern for studying materials on the move, the commodities that crisscross the globe to meet new consumer demands or the parts and raw materials that travel from diffuse settings to be assembled as part of "post-industrial" production processes.

There is a strong "presentist" dimension to this "new mobilities" research which Tim Creswell (2010, p. 29) argues has a "flavour of technophilia and a love of the new about it." Indeed, Creswell (2010, p. 17) has called for "an historical perspective which militates against an overwhelming sense of newness in mobilities research"; both through recognizing that social scientists (and others) have long been interested in mobility and that people and things in the past were also frequently on the move. Movement might, in some cases, have been slower but past historical worlds were not sedentary. However, the "new mobilities" agenda is helpful in provoking a consideration of what a focus on movement and restlessness can do for enhancing our understanding of everyday life in nineteenth-century urban communities. It can also alert us to the problems of "sedentarist" thinking - the treating of stability as the norm; something that is arguably intrinsic to much historical scholarship (Sheller and Urry 2006, pp. 208-212). This is perhaps a particular issue for household archaeological studies which have a focus on domestic life. Home is too often assumed to be a stable, bounded and authentic site of identity formation; where people stay put, resting and sheltering from the frenetic world around them. Yet a growing body of scholarship with both an historical and contemporary focus - has challenged sedentarist understandings of the domestic, emphasizing the importance of mobility both in relation to 
ideas of home and its lived experience and practice (see, for example, Blunt 2007; Blunt and Dowling 2006).

Archaeologists, along with historians, are also beginning to reflect upon the significance of the "mobilities turn." Writing in the introduction to a recent collection of essays entitled Past Mobilities, Jim Leary (2014, p. 16) suggests that "archaeologists ignore the new mobilities paradigm at their peril." Setting newer approaches in the context of older perspectives on mobility, this collection along with a further recent volume edited by Mary Beaudry and Travis Parno (2013), teases out the significance of movement within archaeological analysis and illustrates its constitutive role in shaping economic, social and political relations. No studies of nineteenth-century cities feature in these collections, but it would wrong to claim that historical archaeologists working in such settings have completely ignored questions of movement and mobility, as recent attempts to bring a transnational dimension to household archaeology illustrate (see, for example, Brighton 2009; Murray and Crook 2005). Nor are questions or movement and mobility alien to historians working on Victorian cities. There is, for example, a well-established tradition of the study of residential mobility within the localities and communities of nineteenth-century cities (see for example Dennis 1977a, b, 1984, 2008; Pooley 1979). Certainly, if one compares levels of movement within British Victorian cities with the situation in those places today, then it would seem that there was greater, not less, mobility then than there is now - especially, though probably not exclusively, in poorer districts. Similarly a burgeoning literature on imperial cities has underscored the importance of movements at a global scale of a wide range of people, ideas, products and practices in shaping metropolitan life in London and other large urban centers (see, for example, Driver and Gilbert 1998; Schneer 1999).

Inspired by the "new mobilities" agenda, our aim in this article is to examine the movement of people and things in the poor East London riverside community of Limehouse in the mid-nineteenth century. Drawing upon analysis of archaeological objects retrieved from the privies related to three households in Limehouse, we demonstrate how a focus on mobility can complicate and enhance understanding of everyday life in Victorian cities, providing new perspectives on experiences of being poor in a restless global metropolis.

\section{People and Things in Victorian Limehouse}

Our analysis is based on a study of archaeological artefacts retrieved from the backyard privies serving 14-16 Regent Street (later Gill Street) in Limehouse (Fig 1) in London's East End, excavated in 1993 by the Museum of London Archaeology Service (Museum of London Archaeology or MOLA since 2009). Built as part of an estate development in 1811-12, the buildings the privies served were $15 \mathrm{ft}(4.6 \mathrm{~m})$ wide, two-story terraced properties that represented "classic" examples of turn of the nineteenth century "fourth rate" housing with two rooms on each floor (Guillery 2004, pp. 282-284).

Evidence suggests that by the middle of the nineteenth century the houses were overcrowded. While being questioned by the Select Committee on the Health of Towns in 1840, Robert Heelis, Medical Officer for the Limehouse District of the Stepney Poor 

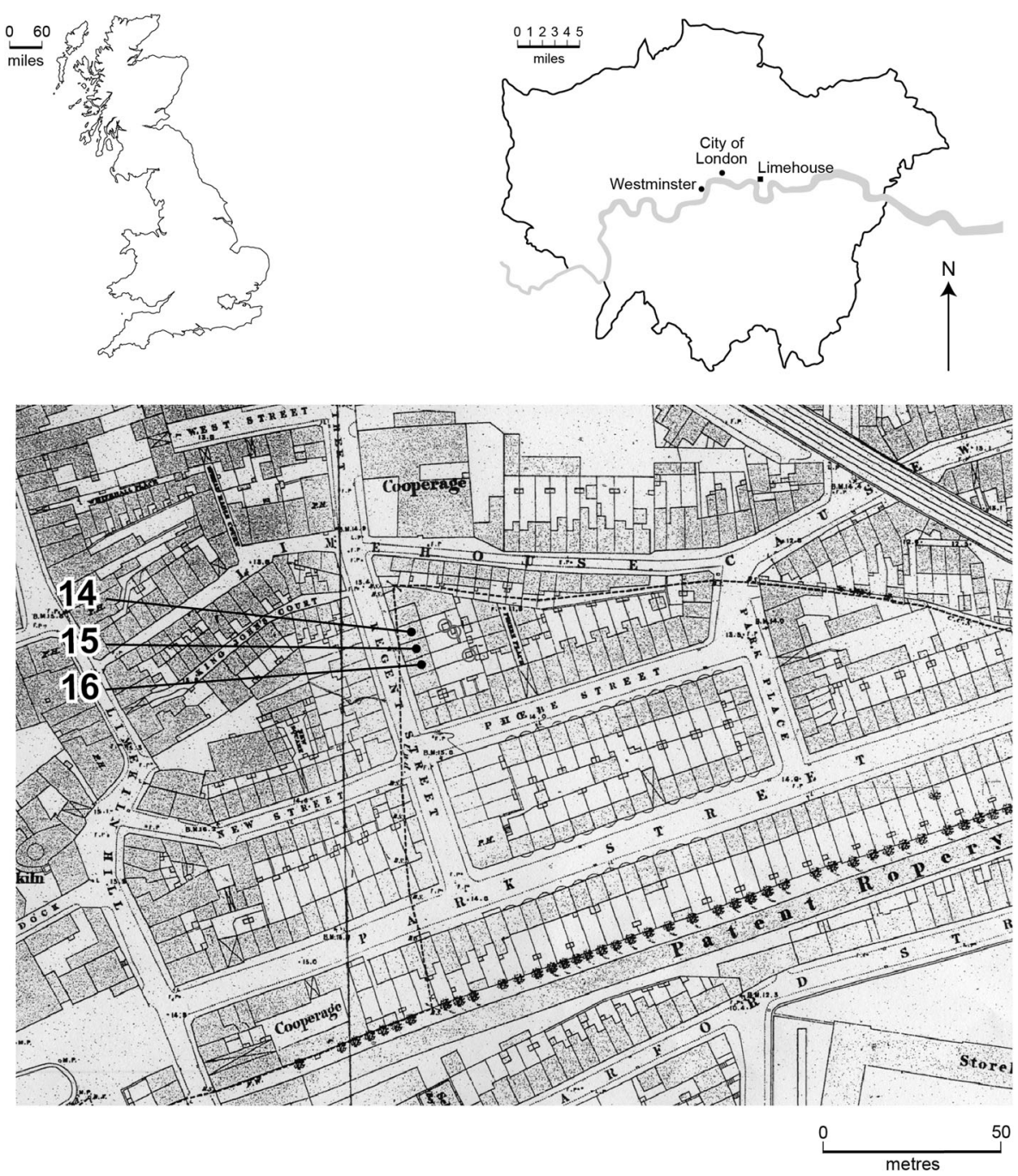

Fig. 1 Location of 14-16 Regent Street, Limehouse, London. The backyard toilet structures (circled) replaced the redundant privies but were built in the same position. The detailed map is taken from the London 1872 Ordnance Survey 1:2500 Map

Law Union, described these newer-build residences as "small houses, occupied always by more than one family" (House of Commons Parliamentary Papers 1840, p. 21). Available census evidence confirms this picture; in 186125 people were recorded as resident at number 16 Regent Street, meaning that conditions must have been cramped. The street's proximity to the Thames - it was no more than 30 yards from the waterfront and its wharves - and the nearby East End docks meant that it was located in one of London's more socially mixed areas, occupied by people who entertained a living from the city's imperial trade. Rather like Allan Pred's (1990) vivid account of the lost worlds of Stockholm's dock communities (a study attentive to questions of mobility), the complex routines and choreographies of maritime capitalism profoundly 
shaped the everyday life of Limehouse residents. Indeed, the area was colorfully portrayed by Charles Dickens in Our Mutual Friend in 1865 (p. 330) as a "ship's hold of waterside characters." Heelis offered further description of the inhabitants of Limehouse, claiming they were "decidedly of the lower class; tradesmen, a very large proportion of mechanics, shipwrights, and engineers; they form the largest portion; and a great many labourers, that get their living by working in the docks" (House of Commons Parliamentary Papers 1840, p. 20). Those residing in the Regent Street houses over the middle decades of the century fit this socioeconomic profile and included a brass founder and his family, shipwrights, an anchor smith, caulker, plumber, dressmaker and various dock laborers, as well as those who did not work, were in education, or were lodging. Indeed, while only offering ten yearly snapshots of who was resident, analysis of the census at street level suggests a crowded neighborhood, where an increasingly diverse community of those who were locally born and those who came from further afield sought to make a living in London's imperial port (see Table 1).

Making a living in the docklands areas of nineteenth-century East London was notoriously difficult; according to Gareth Stedman Jones (1971, p. 113) "dependent on wind and season, riverside labour was by its nature casual and irregular." Giving evidence to the same Select Committee in 1840, Robert Heelis argued that the "very precarious" nature of the local labor market contributed significantly to the poverty of the Limeshouse (House of Commons Parliamentary Papers 1840, p. 24). As one worker who was intermittently employed offloading timber from ships at the nearby West India dock explained to journalist and social investigator Henry Mayhew (1861, p. 295), "jobs come in in a lump - all at once, or none at all; very often with the wind." As a consequence, individuals and families faced a high level of economic insecurity; the morning "call" for work outside the dock gates, where men gathered in large numbers in the hope of being hired for a few hours, was an everyday drama for those seeking an income (Marriott 2012, p. 107). In the 20 years between when Heelis and Mayhew were writing, Stedman Jones (1971, pp. 114-125) argues that London's port was thrown open to increasingly unlimited competition leading to the declining profitability of docks and wharves. Wage rates were also on the slide, with those at the West India Docks falling from 51/2 d per hour in 1802 to $4 \mathrm{~d}$ per hour by the $1850 \mathrm{~s}$. At the same time, the collapse of other East London trades such as silk industry, the building of more efficient mechanized docks further to the East, and the arrival of new

Table 1 Census profile of southern portion of Regent Street, Limehouse, 1841-61

\begin{tabular}{|c|c|c|c|c|c|c|c|c|c|c|}
\hline \multirow{2}{*}{$\begin{array}{l}\text { Year } \\
1841\end{array}$} & \multicolumn{2}{|c|}{$\begin{array}{l}\text { Born in } \\
\text { Middlesex }\end{array}$} & \multicolumn{2}{|c|}{$\begin{array}{l}\text { Born elsewhere in } \\
\text { Great Britain }\end{array}$} & \multicolumn{2}{|c|}{$\begin{array}{l}\text { Born outside of } \\
\text { Great Britain }\end{array}$} & \multicolumn{2}{|c|}{$\begin{array}{l}\text { Working in maritime } \\
\text { occupations }\end{array}$} & \multicolumn{2}{|c|}{$\begin{array}{l}\text { Working in other } \\
\text { occupations }\end{array}$} \\
\hline & 115 & $(66 \%)$ & 55 & $(32 \%)$ & 4 & $(2 \%)$ & 38 & $(70 \%)$ & 16 & $(30 \%)$ \\
\hline 1851 & 79 & $(58 \%)$ & 54 & $(39 \%)$ & 4 & $(3 \%)$ & 31 & $(53 \%)$ & 28 & $(47 \%)$ \\
\hline 1861 & 116 & $(60 \%)$ & 48 & $(25 \%)$ & 30 & $(15 \%)$ & 34 & $(52 \%)$ & 31 & $(48 \%)$ \\
\hline
\end{tabular}

Born outside of Britain: 1841 (Ireland 4); 1851 (Ireland 3, Nova Scotia 1); 1861 (Ireland 24, Germany 3, Hungary 1, India 1, Cape of Good Hope 1)

Source: Census 1841 HO 107/702/10pp. 33-35, HO 107/201/12pp. 27-30; Census 1851 HO 107/1556pp. 745-49. HO 107/1554pp. 586-87; Census 1861 RG 9/288/113pp. 25-30, RG 9/307pp. 87-89 
migrants - particularly, in the 1840s and 1850s, from Ireland (cf Table 1) - created a concentration of underemployed labor. Limehouse lay at the heart of a casual labor market ravaged by structural industrial decay and cyclical depression.

As the century wore on, accounts of the district increasingly elided economic uncertainty with social pathologies and the supposed moral failings of its inhabitants. Often regarded as an ultimate act of metropolitan cartographic condemnation, Regent Street (by then Gill Street) was colored black in Charles Booth's well known Maps Descriptive of London Poverty, published in the 1880s and 1890s, depicting a street occupied by the "lowest class; vicious semi-criminal." It was also at the end of the century that Gill Street became one of the key thoroughfares of Victorian London's Chinatown, represented as both dangerous and exotic in the racialized depictions of novelists and journalists (Seed 2006). Indeed, writing of the turn of the century, John Seed (2006, p. 86) has described Limehouse as "the most cosmopolitan district of the most cosmopolitan city in Britain." As Table 1 hints at, even by the 1850s Limehouse had become a place where long or short-staying migrants resided and sought out their own opportunities to make a living. Among the latter were the estimated 3,000 or so Lascar sailors who set foot British soil every year - mainly, though not exclusively, in London's East End - and the diverse populations catered for by "The Strangers Home for Asiatics, Africans, South Islanders and Others Occasionally Residing in the Metropolis" that was opened on West India Dock Road in Limehouse in 1857 (Visram 1986, pp. 123-124). Also residing in nearby common lodging houses, this wider imperial labor force competed with Irish arrivals, migrants from the provinces and locals for scarce employment opportunities during their temporary stay and were often blamed for the economic insecurities that were inherent to this riverside district.

A diverse range of household objects, including glass, ceramics, clay pipes and other durable artefacts, contained within three defunct privies, were excavated from the rear of 14-16 Regent Street (Table 2). This evidence combined to suggest a likely deposition date of around the mid-1850s for all three of these features. In 1857 the privies appear to have fallen out of use as a new sewer and sanitary facilities were constructed, which by the early 1870 s included outdoor toilets built over the privies' location

Table 2 Materials excavated from 14 to 16 Regent Street, Limehouse by fragment (FC) and minimum number of item (MNI) counts and weights by context

\begin{tabular}{|c|c|c|c|c|c|c|c|c|c|}
\hline \multirow[t]{2}{*}{ Material } & \multicolumn{3}{|c|}{ Context 1} & \multicolumn{3}{|c|}{ Context 3} & \multicolumn{3}{|c|}{ Context 5} \\
\hline & \multicolumn{2}{|c|}{ FC/MNI Count } & \multirow{2}{*}{$\frac{\text { Weight }(\mathrm{g})}{-}$} & \multicolumn{2}{|c|}{ FC/MNI Count } & \multirow{2}{*}{$\frac{\text { Weight }(\mathrm{g})}{-}$} & \multicolumn{2}{|c|}{ FC/MNI Count } & \multirow{2}{*}{$\frac{\text { Weight }(\mathrm{g})}{-}$} \\
\hline Animal bone & 10 & - & & - & & & - & & \\
\hline Clay pipes & 16 & 14 & - & 28 & 28 & - & 10 & 10 & - \\
\hline Glass & 31 & 21 & 1912 & 11 & 3 & 71 & 8 & 8 & 1251 \\
\hline Pottery & 213 & 72 & 13999 & 192 & 61 & 10690 & 224 & 64 & 9421 \\
\hline
\end{tabular}

Except for the category of glass, consistent with Museum of London Archaeology's reporting protocols at the time of analysis, the above statistics exclude 'registered finds' (small or special finds). The registered finds from this site included a range of artefacts such as wooden cleaning utensils, ornaments, cutlery, children's toys, work tools, and medical items. Some of these are discussed elsewhere in this article. For a full report and catalogue see Richardson (2007). For detailed reports on all objects that were excavated see: http://www.geog. qmul.ac.uk/victorianlondon/publications.html (accessed February 16, 2016) 
(Fig 1). Since the early 1830s, the poor state of sanitation in Limehouse, including problems of open sewers, badly maintained and blocked waterways, along with overburdened sanitation systems that brought significant parts of the rest of the East End's human waste through the locality before being emptied into the nearby Thames, prompted a range of petitions, investigations and improvement initiatives (Marriott 2012; see also: Allen 2008; Jeffries 2006). Cholera had twice visited the neighborhood over the period and other forms of disease and "fever" were widespread. As contemporary Parliamentary reports and investigations illustrate, Limehouse was very much a "frontier" of public health debates and sanitary improvements in the middle of the century (see, for example, House of Commons Parliamentary Papers 1834, 1840). By the late-1850s the improving zeal had taken hold with the Medical Officer of Health for Limehouse's Report for the year 1858-59 boasting that amidst a program of new drainage, sewer construction, lighting, street sweeping and public urinal building, no less than 436 cesspools had been "filled up" (Board of Works for the Limehouse District 1859, pp. 32-37). As Regent Street was hooked up to a new sewer, so the original rear garden privies became redundant and were filled with a range of household objects. Like cities in North America, Australia and elsewhere, the abandonment of privy and similar features and their in-filling with unwanted domestic possessions as a result of sanitary improvements has generated an important and understudied resource for archaeologists of nineteenth-century London households. Contemporary accounts suggest that filling privies and similar sanitary features with "cloths, rags and pottery" along with other materials was commonplace, especially in the city's poorer districts (Jackson 2014, p. 251; see also Licence 2015, pp. 1-2). An 1834 petition by Limehouse residents to the authorities to address the problems of poor sanitation, noted how sewers we frequently "choked up ... [with] ... broken vessels, refuse and materials" (House of Commons Parliamentary Papers 1834, p. 160).

Establishing the relationship between the objects found in these privies and those people who lived in adjacent houses was initially a key concern for us, since, true to the ethnographic approach advocated by Mayne and Lawrence (1999), we were eager to contextualize the archaeological finds, building out from an understanding of the household within which they were used to investigate the wider meanings and functions of the objects and the nature of the locality from which they originated. However, after census returns, rate books and other sources that detail household occupancy were consulted, it was clear that we were dealing with a transient community. Apart from one or two individuals, notably widow Elizabeth Garland, owner-occupier at number 15 Regent Street (and also owner of number 14 Regent Street), there was little continuity in terms of who was living at each address over the middle decades of the century. Indeed, it was clear that even the snapshots of occupants obtained from sources like the decennial census and rate books, only captured a portion of the individuals living in and moving through this locality. The household origins of the objects excavated from the sealed privies could not be established with certainty either. While some artefacts evidently came from the immediate locality as they bore the names of a local pubs and a dispensary, as Penny Crook and Tim Murray (2004, pp. 47-48) have noted, it is hard to find definitive evidence of how privies were filled and whether their content came from adjacent households, the wider neighborhood, or from further afield. It therefore became impossible to make definitive claims about exactly who owned and used the artefacts found in the privies at the back of the Regent Street terrace. As others 
have remarked, maritime communities present archaeologists with particular challenges, as the fluidity and diversity of their inhabitants is often even greater than in other urban working-class communities (Praetzellis and Praetzellis 2009, p. 327). Rather than be defeated by this, however, we decided that the only way to proceed was to follow an approach that embraced the transience and mobility of Limehouse's inhabitants and their things. Accordingly we re-oriented our study so that recognition of the mobility of people and objects became a central focus and a key element of our analytical framework.

\section{A City on the Move: Mobility in and Beyond Victorian London}

It is possible to distinguish between various kinds of mobility within Victorian cities, differentiating according to the scale of the movement (the distance travelled and the time taken), the frequency of that movement, and the purposes of moving. Here we consider three sorts of mobility: international migration, local residential mobility, and the micro movements of people and things in the context of daily domestic routines. In each case we demonstrate how a focus on mobility can cast new light on and raise fresh questions about the experiences and struggles of poor people who sought to make a living in and beyond a global metropolis for, as Creswell $(2006,2010)$ has pointed out, there is a politics to people's mobility rooted in the exercise of power and the experience of inequality.

\section{Global Lives in mid-Nineteenth-Century Limehouse}

Mid-nineteenth-century Limehouse was a locality profoundly shaped by the movement of people and things at a global scale. For those who came from the empire and other overseas locations, the distinctive landmark tower of St Anne's Limehouse (a church designed by the architect Nicholas Hawksmoor, consecrated in 1730) announced their arrival in London and, for many, the parish was where they first set foot on metropolitan soil. A dense thicket of ships' masts and rigging filled the nearby West India Docks and barges clung to the wharves on the Limehouse river front, where cargoes of goods from the familiar to the exotic were off-loaded. Dock laborers daily handled objects and commodities that in many cases had literally travelled half way across the globe to be brought ashore in Limehouse and surrounding riverside districts. But, as Jonathan Schneer (1999, pp. 44-45) has argued in his study of the docks at the end of the nineteenth century, the casual dockworkers who offloaded the bounties of British imperial trade, rarely got to take a share. Even if imports were temporarily halted to be processed, transformed and packaged in nearby distilleries, refineries and warehouses, these objects did not come to rest in Limehouse, they were still in motion. They were moved on to the developing commercial centers of the West End or to provincial towns and cities, eventually ending up in elite country houses and middleclass parlors. It is perhaps not surprising, therefore, that in spite of its proximity to a global port, the artefacts found in the Limehouse privies do not register a strong imperial "signal" and are mostly British-made. Two exceptions include a bamboo fan handle from the "Orient," perhaps a gift from a sailor, and an older, porcelain tea pot originating from China. This latter item appears to have been used for some time (and 
therefore stayed put in Limehouse); it dates from the late eighteenth century and its iron handle suggests that it was repaired and restored after an earlier breakage (See Fig. 2). The act of repairing the vessel perhaps underlines the value of the object to it former owners, a rare case of where the circulation of exotic and luxury goods had not bypassed poorer groups.

Other objects point more directly to the influences of the global mobility of people and things on Limehouse and its inhabitants. This mobility was embedded in the economic fabric of the locality, with census and trade directory evidence suggesting most people made a living from loading and off-loading ships' cargoes, and repairing and refitting sailing vessels, alongside providing lodging, food and drink for sailors and locals alike. Not surprisingly evidence of the work that underpinned global maritime shipping is present in the archaeological record which includes a range of lead, wooden and copper alloy fittings associated with sea vessels and river barges, such as unfinished sheaves made of a hard South American wood with a parrel bead from a ship's rigging. Three wooden pulley blocks, recovered from the privy of 15 Regent Street, perhaps point to the work of Henry Sampson, a shipwright who lodged at this address with his family in the 1850s. The presence of these objects in domestic privies suggests that the division between home and work was not clear cut within poor households, a feature of the metropolitan economy (Green 1996). Their presence also points more obliquely to the rhythms and experiences of work in this locality: the intensive and frenetic nature of a maritime economy, where individuals like Sampson labored hard in cramped, noisy and precarious conditions to keep vessels sea-worthy.

The well-known precarity of dock labor and maritime work in Victorian London, was one kind of domestic insecurity facing those attempting to make a living in Limehouse (Stedman Jones 1971). The livelihoods of others required them to leave Limehouse on ships that took them away from London's East End for months at a time. The city's working-class sailors were globally mobile as they washed back and forth from dockside neighborhoods on the tides of imperial trade. To such maritime households, the relative security of a seaman's wage was tempered by the long periods of absence and uncertainty that disrupted domestic relationships and led to emotional upheavals. Contained within the privies of 14 and 16 Regent Street were two

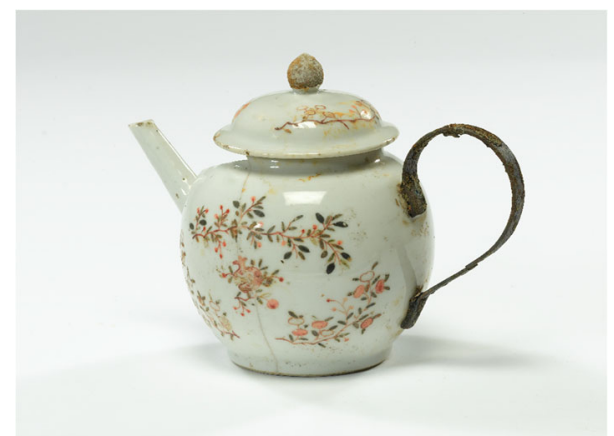

Fig. 2 Chinese porcelain teapot and lid with replacement riveted iron handle (Site Code LHC93, from context 1) from 14 Regent Street. Photograph by Andy Chopping, reproduced by kind permission of MOLA (Museum of London Archaeology) 
ornamental glass rolling pins with overgrazed enameling and feint decorative motifs (Fig. 3). Principally manufactured in Bristol, Newcastle or Sunderland glasshouses, such items have been found in a number of maritime communities and were traditionally hung by a silk cord or ribbon above a fire place when a sailor went to sea. (Similar examples exist in the collections of the Victoria and Albert Museum, London. See C.697-1921 and C.916-1925.) Intended as a token of love and fidelity, superstition held that if the rolling pin were to fall and break, the ship of the absent sailor had been lost to the sea or he had absconded with another woman. Left broken and discarded in the privy it is unfortunately not possible to ascertain whether such a calamity might have befallen its owner. However, its presence points to the cultural rituals that surrounded oceanic mobility in the age of sail as individuals and communities sought to cope with the risks of the seas and uncertainties of separation. In this example, it is an artifact that gets left behind - that stays still and does not travel with a member of the household that alerts our attention to the global mobility that was a feature of communities in midnineteenth-century London. Objects that held similar symbolic and emotional significance can be found across northern European traditions of maritime material culture (Rudolph 1985). For example, in seafarers' cottages and dwellings on the Nordic, Danish and Swedish coastlines, there was a tradition of placing Staffordshire - made ceramic spaniel figures (Kenny 1997) in window sills to denote whether the man of the house was at sea (placed looking out of the window) or at home (turned looking inwards) (for a discussion of these and similar practices, notably in Raahe in Finland, see Symonds et al. 2009).

Like the ballads that were sung in communities where men went frequently to sea, objects like the rolling pins served to keep memories alive and reduce the emotional insecurities that global mobility brought. They suggest something of the affective and embodied apprehensions that movement gives rise to (Merriman 2012). While traveling half way across the world on sometimes dangerous and risky voyages was a major event in an individual's life and profoundly disrupted the stability offered by domestic life and relationships, in a place like Limehouse such moves must have seemed relatively routine, a familiar struggle and shared everyday experience. And perhaps other objects that were in the privies were also things that got left behind by those travelling abroad, thrown away or donated to a friend or family member who later disposed of them. Could the mis-matched tablewares that comprise part of our assemblages be evidence of household objects that were abandoned - the material residues of individuals who had moved overseas?

\section{Local Residential Mobility, Property and Possession}

Most moves in nineteenth-century cities were more local. Studies of Victorian cities have shown high levels of intra-urban mobility, with the lower status groups and families with young children changing addresses most frequently (Pooley 1979). Research undertaken by Pooley (1979), who mainly worked on nineteenth-century Liverpool, by Dennis (1977a, b) who examined mobility in Huddersfield and then later (2008) in London, as well as Green (1986) and Green and Parton (1990), who also worked on Victorian London, has demonstrated that moves were local and frequent people might change address several times a year - leading to the interesting conclusion that that in spite of intensive mobility there was still a degree of community stability 


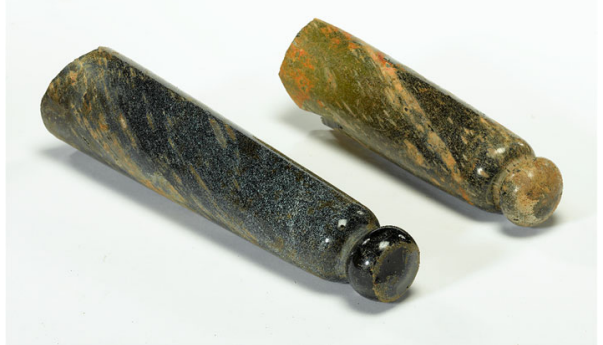

Fig. 3 Ornamental glass rolling pins recovered from 14 to 16 Regent Street, Limehouse (Site Code LHC93, Museum of London Accession Numbers: 107 and 116, from contexts 1 and 5, respectively). Photograph by Andy Chopping, reproduced by kind permission of MOLA (Museum of London Archaeology)

within poor neighborhoods. As already noted evidence from Limehouse suggests that there was a high turnover of residents on Regent Street. Robert Heelis (Medical Officer of Health for Limehouse) commented that the neighborhood's laboring classes were "very migratory" and that they "remove their residences ... frequently" (House of Commons Parliamentary Papers 1840, p. 24). Understanding why people move is more difficult, but studies of residential mobility suggest issues such as labor market insecurity discussed above and changing family dynamics were important. Frequent moves can be interpreted as an economic strategy, a process of "up-sizing" and "downsizing" as individual and family fortunes waxed and waned. The season, the weather, the amount of daylight, patterns of trade and war alongside longer term cyclical economic trends, were all factors influencing employment opportunities (Stedman Jones 1971, pp. 118-125). It is plausible that frequent moves in this neighborhood might have been response to these uncertainties as well as to other events that could dramatically shape the well-being of poorer families - accidents, illness, sudden death, or, as just noted, the departure of individuals travelling overseas. As Stedman Jones (1971, pp. 79-80) also argues, casual labor itself was very mobile with workers moving from one casual trade to another in order to maintain an income.

Bringing this kind of mobility to the fore in studies of nineteenth-century household archaeology is, we think, helpful as it draws attention to the way that the circumstances of families and individuals were shaped by wider structural economic forces. If moving is seen as an economic strategy that responds to these wider structural processes as well as something that reflects more personal needs, priorities and desires of individuals and families, then a focus on mobility offers one way of keeping in view the exploitation that people faced and the struggles that they shared with others to make a living. Moving locally addressed short term economic priorities and opportunities without disrupting friendships or undermining local support networks (cf Ross 1983, 1993).

The question that remains, however, is what consequence does recognition of this kind of intra-urban, often very local mobility have for the interpretation of our archaeological finds and for understanding the everyday lives of the poor in neighborhoods like Limehouse? In a more recent article, Colin Pooley (2009) draws attention to the fact that not much is known about how people moved in the nineteenth century. How easy was it to move people and their material possessions on a regular basis? One of the insights gained from nineteenth-century household archaeologies is the significant volume of objects that even poorer people seemed to have access to. In 
contemporary societies moving those objects and repositioning them in a new dwelling - a dwelling that has perhaps even been selected with the arrangement of personal possessions in mind, is a common home-making practice and a central concern in the moving process. However, to assume this was always the case in the past would perhaps be to cast a contemporary consumerist gaze on the domestic history of the poor. Given that people moved more frequently, were they always concerned to carry all their personal possessions with them? In situations where there was multiple occupancy of buildings and large numbers of lodgers - commonplace in Victorian Limehouse (the 1851 census reveals number 22 Regent Street to be a lodging house) as in other poor parts of the city - to what extent was the ownership and use of core domestic objects such as cooking utensils, cleaning equipment and tableware, a more communal matter? What were commonly practised rights and entitlements in relation to the use of objects by different categories of household residents: lodgers, tenants and occupiers, for example? Are the jumbled up fragments of at least four different transferprinted tableware patterns applied to the few different-sized plates that we found in the privy of number 14 Regent Street simply the material trace of the complex comings and goings of different individuals, who brought items with them, shared what was already there, but also left things behind? When incomes could not keep up with rent demands, lodgers might be forced to move on, perhaps even doing a "moonlight flit," escaping under the cover of darkness and likely leaving many of their possessions behind (Gilfillan 2014, p. 83). In his work exploring those who were temporary lodgers in eighteenth-century London, John Styles (2006) raises important questions about whether temporary residents carried around their own domestic kit or whether they rented finished and ready-equipped premises. A combination seems likely and his suggestion that most items would have been "reused, recycled or second-hand" would help to explain the eclectic nature of the dinnerware assemblages from the houses on Regent Street. It is hard here to offer definitive evidence in support of these suggestions, but they seem plausible, particularly in a locality like Limehouse where there was such a churn of people.

These questions raise some more fundamental issues about how we conceive of the way that nineteenth-century households and individuals (especially those in poorer communities) considered the ownership, entitlement and use of household possessions. Our consumerist eyes perhaps encourage us to conceive of the relationship between people and household objects in a way that emphasizes notions of possessive individualism. Things were acquired for the sole and absolute use of those purchasing them to be exclusively appropriated for their functional and symbolic needs and not necessarily anyone else's. But is this to impose a liberal conception of property ownership on the past that might not have reflected everyday practice? Where entitlement to and use of objects might have been more fluid and communal - precisely because of the intensity of residential mobility in metropolitan neighborhoods - should we be so anxious about proving ownership, tying particular people to particular things? We know from other studies of slum communities in Victorian London, notably those by Ellen Ross (1983, 1993), that (gendered) networks of communal support and systems of reciprocity and sharing were common in such circumstances. In the North American context Susan Strasser (1999) has sought to emphasize the importance of the stewardship (rather than exclusive ownership) of goods within poorer neighborhoods where items would be repaired, reused, repurposed and passed on. There was a fluidity to 
the ownership and use of objects; consumption implying a form digestive appropriation would seem an inappropriate way of describing people's relationship to things.

The literature on pawning strategies, for example (i.e., Lemire 2005; Tebbutt 1984), where valued objects would temporarily move out of a household and into a pawn shop (there were several of these in Limehouse) before perhaps being bought back again, at least demonstrates that claims to exclusive ownership might be surrendered or relinquished for a period of time. The importance of pawning is highlighted in records of theft cases heard at the Old Bailey where stolen items were frequently recovered from local pawnshops (there were 14 such cases in the vicinity of Regent or Gill Street between 1820 and 1861, mainly relating to thefts of clothing and items of adornment such as watches). (See, for example, Trial of James Bridgman, Old Bailey Proceedings Online, www.oldbaileyonline.org t18420228-968.) In several cases pawnbrokers were called to give evidence as they were often with familiar with objects that moved in out of their shops and were therefore aware that items were stolen. While an Old Bailey Court case clearly represents an attempt to (re)assert rights of ownership over stolen goods, it also points to pawning as one the mechanisms by which everyday objects where circulated around this neighborhood. Most significantly, as scholars like Ellen Ross (1993, 81-84), Beverley Lemire (2005) and Melanie Tebbutt (1984) have shown pawning, an activity often undertaken by women, was a source of credit to poor households who made pledges on their possessions in order to make ends meet during moments of hardship. The ability to move objects into a pawnshop was a strategy for dealing with chronic want - a way of coping with the insecurities of a weekly wage which would not always stretch far enough.

\section{Micro-Moves: Domestic Labor and the Everyday Routines of the Poor in Limehouse}

Having considered global mobility and local residential moves, the final kind of movement that we want to focus is the micro movement of things that formed part of daily routines within the spaces of the household and the immediate locality. As we have already hinted at, many of the objects that were found in our Regent Street privies would have been used for the preparation and consumption of food and drink as well as for other tasks of domestic reproduction. As part of the routines of domestic labor these objects would have been moved over short distances hundreds if not thousands of times, from cupboard to cooking range, or water pump to table and so on. The mobility of objects at this micro-scale highlights the rhythms of daily life, especially the routines and chores that were central to the experience of poorer women (Owens et al. 2010b). In short, this kind of mobility of domestic archaeological artefacts brings into view the household as a site of labor and gender inequality. The repetitive daily routines of household labor that were mainly performed by women are palpable within the archaeological record if not always in other historical sources. As Spencer-Wood (2004) has suggested, archaeological evidence can offer insights into gendered divisions of labor by pointing to everyday experiences and routines of domestic work and highlighting is social and economic contribution. For Yamin (2001c), considering archaeological artefacts such as these "in use" - or "in motion" we might 
say - (as opposed to in their sedantry state discarded in the privy) uniquely positions women as central characters in poor neighborhoods, demonstrating their energy and struggles in ensuring survival and well-being through the "drudge" of domestic work (cf Ross 1993).

Indeed, the material paraphernalia deployed in what Lee Jackson (2014) has called the Victorian "fight against filth" - perhaps spearheaded by women like Elizabeth Jones and Sarah Gibbons resident at 14 Regent Street in the 1850s - figure prominently in the Limehouse object assemblages. These include well-worn scrubbing brushes for cleaning doorsteps and floors (see Fig. 4), wooden pegs for hanging washing in the back yard and two stoneware black leading bottles, likely used for cleaning cooking ranges and other cast iron equipment. A collection of three cylindrical glass medicine phials points to efforts to secure the health and well-being of family members (see Fig. 5). While probably containing homeopathic remedies for treating minor ailments, the area had a reputation for being sickly: the first case of cholera in the London epidemic of 1832 was discovered in Limehouse and there were further outbreaks in 1848, 1858 and 1866 (Marriott 2012). Finally, the daily grind of quelling hunger and providing food is attested to by a wide variety of cooking equipment, scratched, scorched and cracked though years of use. Moved around different household spaces as it was being used, this material evidence points to the struggles of domestic reproduction in a dirty, unhealthy and economically precarious part of the city.

Nowhere is this more apparent than in the evidence of tableware settings and the insights they offer about mealtimes. In all three privies the numerous ceramic yellowware "London-shape" rounded bowls and more mismatched refined whitewares with either mocha, banded and cat's eyes industrial slip decoration applied (Sussman 1997; these last vessels can be dated to the earlier nineteenth century), represent the principal means by which foods were eaten, suggesting that economical one pot meals, such as soups, stews and porridges were important. Table cutlery - an uncommon constituent in the rubbish discarded in London's abandoned privies - is also present and includes five worn lead nickel plated dining and serving spoons used by the occupants of number 14 Regent Street. The few plates located in both the privies of 14 and 15 Regent Street are individual and mismatched, with the most complete - two whiteware plates with even-scalloped blue shell-edge decoration on the rims (Miller et al. 2000, p. 3, Fig. 5) from 14 Regent Street - being at least 20 years old when discarded. Frequent

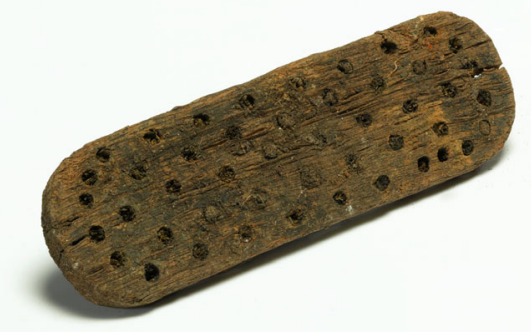

Fig. 4 Wooden scrubbing brush (oak) from 14 Regent Street, Limehouse (Site Code LHC93, Museum of London Accession Number: 10, from context 1). Photograph by Andy Chopping, reproduced by kind permission of MOLA (Museum of London Archaeology) 


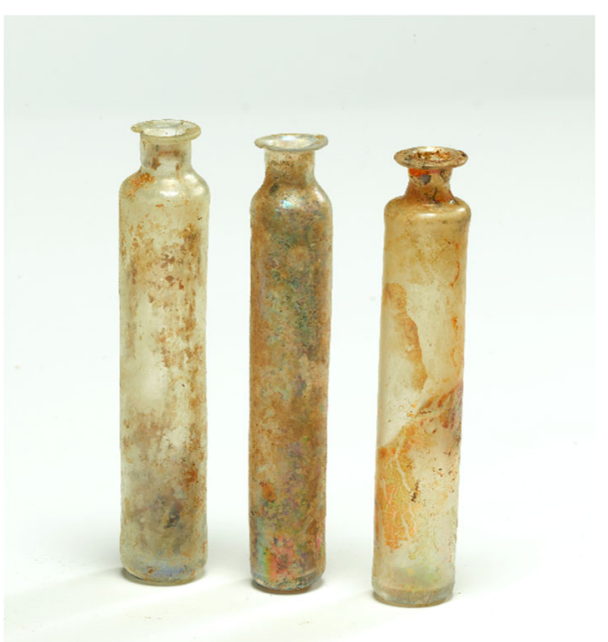

Fig. 5 Glass pharmaceutical phials from 14 Regent Street, Limehouse (Site Code LHC93, MOLA Accession Numbers: 98, 99 and 100, from context [1]). Photograph by Andy Chopping, reproduced by kind permission of MOLA (Museum of London Archaeology)

cutlery marks attest to heavy use. Although plates are generally uncommon, both privies contained a few examples of each decorated with the blue Willow pattern transfer-print, a design that featured on much of the crockery that Londoner's ate their meals off (Jeffries et al. 2009, pp. 335-336; Owens et al. 2010a). Little further diversity in settings is otherwise displayed with the plain refined whiteware oval serving dish, eggcup and pepper caster and blue-transfer-printed mustard pot lid supplying the only "specialist" ceramic tablewares acquired by both households (see Praetzellis and Praetzellis 2009, p. 353, for discussion of specialist tablewares in San Francisco's maritime community). Mismatched both in terms of aesthetic quality but also in relation to when they were acquired, this range of dining crockery represents either part of the stock of equipment supplied by a landlord or that which had been accumulated and left behind as tenants moved on. Practical and functional considerations appear to have overtaken any emulation of middle-class table settings (whether desired or not). Quickly taken meals appeared more important and as discussed by Webster (1999, p. 71), a preference for bowls over plates has been observed in other nineteenth-century settings and interpreted as "reflecting local dietary preferences and eating arrangements" in households that otherwise lacked tables and chairs to allow for formalized dining.

Daily routines that took people beyond the immediate walls of the household in search of other forms of sustenance are pointed to by an object found at 14 Regent Street: a pewter quart measure, stamped with a crowned "WR" (for William IV: 183037) (Fig. 6). Pewter supplied the bulk of the items used for the taking of alcohol in London's drinking establishments until glass became cheaper to manufacture in the early twentieth century. Although it once represented a familiar sight, nineteenthcentury examples rarely survive in the present because of pewter's recycling and scrap value. This measure is further marked with "W. Williams Spread Eagle Limehouse," 


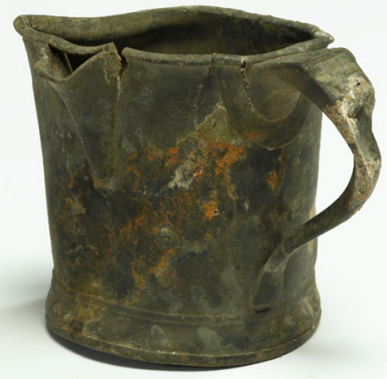

Fig. 6 Pewter quart measure from 14 Regent Street, Limehouse (Site Code LHC93, Museum of London Accession Number: 25, from context 1). Photograph by Andy Chopping, reproduced by kind permission of MOLA (Museum of London Archaeology)

inscribed within a shield, and with "W A W" initials on the handle thumb rest. The Spread Eagle was a pub located very close to 14 Regent Street on the corner of Limehouse Causeway and Regent Street, and William Williams was the first landlord of this establishment from 1816 until he departed for Australia in 1841. Its original and intended place of use is therefore clear and by commissioning a pewterer to inscribe his name and that of his pub, Williams therefore followed the well-trodden path of others in his profession in ensuring that if this measure was stolen, ownership could be easily proved. The proceedings of Old Bailey trials regularly detail the theft of pewter measures and tankards from various drinking establishments. Yet this example was discarded in the privy some 16 years after Williams had left the Spread Eagle for Melbourne. The appearance and use of this quart measure at 14 Regent Street is therefore removed from its original function of decanting drinks and, we should note, providing proof to the Spread Eagle's customers that Williams served beverage volumes that adhered to legal standards. Now used in a domestic dwelling that otherwise displayed little material evidence of alcohol consumption, restricted to a few mismatched but older wine glasses and a decanter, we can speculate but never determine the set of events and motivations behind the removal of this measure from the Spread Eagle. Three scenarios appear possible. The first is that it was sold on (after Williams had left) and purchased by a resident of 14 Regent Street. The second is that it was gifted or loaned by William Williams who offered the measure to a loyal patron of the Spread Eagle - a regular customer who traversed the street on a daily basis for an alcoholic fix, sociability and relaxation - perhaps on the occasion of his departure for Melbourne. After this time the measure's explicit reference to a former landlord comprised its utility value while enhancing its status as a token by which to remember a now disappeared friend and community member. Finally, it could, of course, have been stolen in the way that Old Bailey records describe the fate of other pewter measures and tankards belonging to pubic houses. Like so much of the surviving archaeology, the presence, meaning and significance of the pewter measure in unclear and ambiguous. It might have been illegally removed from the pub but it might also be read as part of the domestic material culture of reciprocity - the material traces of a 
moral economy where things were donated, loaned and shared to enable people to "get by," or as a token by which to remember a familiar face who had moved away.

\section{Conclusion}

In focusing on the issue of mobility - the way that people and objects move through space and time - we hope to have rekindled interpretative possibilities for the study of nineteenth-century household archaeology. Our article was inspired by a methodological problem associated with artefact-led studies of poor communities in nineteenthcentury cities. We believe that placing mobility as a central analytical focus of research as opposed to casting it as an issue that prevents understanding of the routines and experiences of poor communities does more than help us to sidestep tricky methodological issues. As a focus, it is potentially liberating, allowing us to think more about how and why objects were used and disposed of and how they both reflect and shape urban lives that rarely stood still. We believe that the question of mobility also highlights wider issues of power and inequality, pointing to the collective experiences and struggles that individuals, families and communities were engaged in the face of the structural constraints and volatility of metropolitan mercantile capitalism. Echoing the proponents of the "ethnography of place" approach, such a perspective also reminds us that historical archaeologists always need to look beyond the scale of the household in their analyses. Most of the residents of mid nineteenth-century Limehouse were not anchored to a particular household and we should not fall into the trap of interpreting the material traces they left there as evidence of domestic stability. Panning out to the scale of the neighborhood enables us to better understand more of the context to people's mobility. Attending to the economic and social fabric of a place - with its formative connections to other places, both near and distant - arguably provides a more fruitful way of interpreting the archaeology of nineteenth-century poverty.

Proponents of the "mobility turn" have claimed that in order to make sense of a world in motion we need new methodological tools (Buscher and Urry 2009). If "mobile ethnography" has become a buzz word of new approaches seeking to capture movement and mobility and highlight their deep significance and effects, historians and historical archaeologists are more limited in their ability to deploy such approaches to investigate people and things in the past. But in developing the "ethnography of place" approaches advocated by historical archaeologists of nineteenth-century cities, we could at least aspire to generate an "ethnography of mobility" which takes as a starting point the restlessness and fluidity of place, and the dynamic relationships between people and things. If some historical archaeologists can detect a touch of the "emperor's new clothes" about this "mobility turn," then it at least prompts us to consider on some the ways that the discipline has previously thought about movement in order to reflect back on more recent debates. In this respect the longer standing notion of "transience" not only describes a methodological challenge to studying poor nineteenth-century places, it also captures a form of movement or drifting that is largely at the mercy of external forces. More intellectually fashionable ideas of "mobility" seem to reflect a bourgeois conception of movement based on choice, power and agency. We would do well to hold on to the idea of "transience" and other forms of movement that were often simply responsive to the wider structural circumstances that formed a context to poor 
people' lives. Indeed, recognizing and understanding how and why people moved is, we would argue, key to writing good ethnographies of nineteenth-century urban places.

Acknowledgments We are grateful to the UK's Arts and Humanities Research Council who funded the research upon which this paper is based (Grant Reference AH/E002285/1): 'Living in Victorian London: Towards a Material History of Everyday Domestic Life in the Nineteenth-Century Metropolis' (see: http://www.geog.qmul.ac.uk/victorianlondon). We would like to thank the other members of the project's core team - Rupert Featherby and Karen Wehner - for their key insights and contributions, and colleagues at MOLA (Museum of London Archaeology) who supported aspects of the research and analysis including, Jacqui Pearce, Alan Pipe, and Beth Richardson. We are also grateful to Lee Jackson and Tom Licence - fellow enthusiasts of Victorian rubbish - for their advice and suggestions, and to participants at seminars and conferences in York, London and Cambridge, UK for stimulating discussion and ideas. We are grateful to Ed Oliver for drawing Fig. 1. Finally, we thank the journal's two readers for their encouraging comments and suggestions.

\section{Compliance with Ethical Standards}

Conflict of Interest The authors declare that they have no conflict of interest.

Open Access This article is distributed under the terms of the Creative Commons Attribution 4.0 International License (http://creativecommons.org/licenses/by/4.0/), which permits unrestricted use, distribution, and reproduction in any medium, provided you give appropriate credit to the original author(s) and the source, provide a link to the Creative Commons license, and indicate if changes were made.

\section{References}

Allen, M. (2008). Cleansing the City: Sanitary Geographies in Victorian London, Ohio University Press, Athens.

Beaudry, M., and Parno, T. G. (eds.) (2013). Archaeologies of Mobility and Movement, Springer, New York.

Blunt, A. (2007). Cultural geographies of migration: mobility, transnationality and diaspora. Progress in Human Geography 31: 682-694.

Blunt, A., and Dowling, R. (2006). Home, Routledge, Abingdon.

Board of Works for the Limehouse District (1859). Statement of Accounts, Report, \&c., from Lady-day 1858, to Lady-day, 1859, Metropolitan Board of Works, London.

Brighton, S. A. (2009). Historical Archaeology of the Irish Diaspora: A Transnational Approach, University of Tennessee Press, Knoxville.

Buscher, M., and Urry, J. (2009). Mobile methods and the empirical. European Journal of Social Theory 12: 99-106.

Creswell, T. (2006). On the Move: Mobility in the Modern Western World, Routledge, London.

Creswell, T. (2010). Towards a politics of mobility. Environment and Planning D: Society and Space 28: 17-31.

Crook, P. (2011). Rethinking assemblage analysis: new approaches to the archaeology of working-class neighbourhoods. International Journal of Historical Archaeology 15: 582-593.

Crook, P., and Murray, T. (2004). The analysis of cesspit deposits from The Rocks, Sydney. Australasian Historical Archaeology 22: 44-56.

Dennis, R. (1977a). Intercensal mobility in a Victorian city. Transactions of the Institute of British Geographers 2: 349-363.

Dennis, R. (1977b). Distance and social interaction in a Victorian city. Journal of Historical Geography 3: $237-250$.

Dennis, R. (1984). English Industrial Cities of the Nineteenth Century: A Social Geography, Cambridge University Press, Cambridge.

Dennis, R. (2008). Cities in Modernity: Representations and Productions of Metropolitan Space, 1840-1930, Cambridge University Press, Cambridge. 
Dickens, C. (1865 [2002]). Our Mutual Friend, Wordsworth Editions, Ware.

Driver, F., and Gilbert, D. (1998). Heart of empire? Landscape and performance in imperial London. Environment and Planning D: Society and Space 16: 11-28.

Gadsby, D. (2011). "We had it hard... but we enjoyed it": class, poverty and pride in Baltimore's Hampden. Historical Archaeology 45(3): 11-25.

Gilfillan, R. (2014). Crime and Punishment in Victorian London: A Street-Level View of the City's Underworld, Pen \& Sword Books, Barnsley.

Green, D. R. (1986). People of the Rookery: A Pauper Community in Victorian London, Occasional Paper 26, King's College London, London.

Green, D. R., and Parton, A. (1990). Slums and slum life in Victorian England: London and Birmingham at mid-century. In Gaskell, M. (ed.), Slums, Leicester University Press, Leicester, pp. 71-91.

Green, D. R. (1996). The nineteenth-century metropolitan economy: a revisionist interpretation. The London Journal 21: 9-26.

Guillery, P. (2004). The Small House in Eighteenth-Century London: A Social and Architectural History, Yale University Press, London.

Hannam, K., Sheller, M., and Urry, J. (2006). Editorial: mobilities, immobilities and moorings. Mobilities 1: 1-22.

Hicks, D., and Beaudry, M. (2010). The Oxford Handbook of Material Culture Studies, Oxford University Press, Oxford.

House of Commons Parliamentary Paper (1834). Report from Select Committee on Metropolis Sewers; with Minutes of Evidence, and an Appendix. Her Majesty's Stationery Office, London.

House of Commons Parliamentary Paper (1840). Report from the Select Committee on the Health of Towns; Together with the Minutes of Evidence Taken Before Them, and an Appendix and Index. Her Majesty's Stationery Office, London.

Jackson, L. (2014). Dirty Old London: The Victorian Fight Against Filth, Yale University Press, London.

Jarrett, K. (2013). Living in the past: exploring everyday life during and after the Victorian period in an East Midlands industrial town' Journal of Victorian Culture Online, http://blogs.tandf.co.uk/jvc/2013/02/22/livingin-the-pastexploring-everyday-life-during-and-after-the-victorian-period-in-an-east-midlands-industrial-town/.

Jeffries, N. (2006). The Metropolis Management Act and the archaeology of sanitary reform in the London Borough of Lambeth 1856-86. Post-Medieval Archaeology 40(2): 272-290.

Jeffries, N., Owens, A., Hicks, D., Featherby, R., and Wehner, K. (2009). Rematerialising metropolitan histories? People, places and things in modern London. In Palmer, M., and Horning, A. (eds.), Crossing Paths or Sharing Tracks: Future Directions in the Archaeological Study of post-1550 Britain and Ireland, Boydell and Brewer, Woodbridge, pp. 323-350.

Kenny, A. (1997). Staffordshire Spaniels: A Collector's Guide to History Styles and Values, Schiffer Publishing Limited, Atglen.

Leary, J. (2014). Past mobility: an introduction. In Leary, J. (ed.), Past Mobilities: Archaeological Approaches to Movement and Mobility, Ashgate, Farnham, pp. 1-20.

Lemire, B. (2005). The Business of Everyday Life: Gender, Practice and Social Politics in England, c. 16001900, Manchester University Press, Manchester.

Licence, T. (2015). What the Victorians Threw Away, Oxbow Books, Oxford.

Marriott, J. (2012). Beyond the Tower: A History of East London, Yale University Press, London.

Matthews, C. N. (2011). Lonely islands: culture, community, and poverty in archaeological perspective. Historical Archaeology 45(3): 41-54.

Mayhew, H. (1861). London Labour and the London Poor, Volume III, Griffin Bohn and Company, London.

Mayne, A. (2007). Tales but true? New York's Five Points' slum. Journal of Urban History 33: 320-331.

Mayne, A. (2008). On the edges of history: reflections on historical archaeology. American Historical Review 113: 93-118.

Mayne, A., and Lawrence, S. (1999). Ethnographies of place: a new urban research agenda. Urban History 26: 325-348.

Mayne, A., and Murray, T. (2001a). The archaeology of urban landscapes: explorations in slumland. In Mayne, A., and Murray, T. (eds.), The Archaeology of Urban Landscapes: Explorations in Slumland, Cambridge University Press, Cambridge, pp. 1-7.

Mayne, A., and Murray, T. (eds.) (2001b). The Archaeology of Urban Landscapes: Explorations in Slumland, Cambridge University Press, Cambridge.

Merriman, P. (2012). Mobility, Space and Culture, Routledge, Abingdon.

Miller, G. L., Samford, P., Shlasko, E., and Madsen, A. (2000). Telling time for archaeologists. Northeast Historical Archaeology 29(1): Article 2. http://digitalcommons.buffalostate.edu/neha/vol29/iss1/2.

Murray, T., and Crook, P. (2005). Exploring the archaeology of the modern city: issues of scale integration and complexity. International Journal of Historical Archaeology 9: 89-109. 
Orser, C. (2011). The archaeology of poverty and the poverty of archaeology. International Journal of Historical Archaeology 15: 533-543.

Owens, A., Jeffries, N., Featherby, R. and Wehner, K. (2010a). From the unusual to the banal: the archaeology of everyday life in Victorian London. Research Matters, No. 4, Museum of London Archaeology, London.

Owens, A., Jeffries, N., Wehner, K., and Featherby, R. (2010b). Fragments of the modern city: material culture and the rhythms of everyday life in Victorian London. Journal of Victorian Culture 15: $212-225$

Pooley, C. G. (1979). Residential mobility in the Victorian city. Transactions of the Institute of British Geographers 4: 258-277.

Pooley, C. G. (2009). How people moved: researching the experience of mobility in the past. Local Population Studies 82: 63-70.

Port, A. I. (2015). History from below, the history of everyday life and microhistory. In Wright, J. (ed.), International Encyclopedia of the Social and Behavioral Sciences, volume 11, 2nd ed, Elsevier, New York, pp. 108-113.

Praetzellis, M., and Praetzellis, A. (eds.) (2004). Putting the 'There' There: Historical Archaeologies of West Oakland, Anthropological Studies Centre, Sonoma State University, Rohnert Park.

Praetzellis, M., and Praetzellis, A. (eds.) (2009). South of the Market: Historical Archaeology of 3 San Francisco Neighbourhoods, Volume II, Anthropological Studies Centre, Sonoma State University, Rohnert Park.

Pred, A. (1990). Lost Words and Lost Worlds: Modernity and the Language of Everyday Life in late Nineteenth-Century, Cambridge University Press, Cambridge.

Richardson, B. (2007). The Registered Finds from the Cyril Jackson School, Limehouse Causeway, Museum of London Archaeology Service, London. http:/www.geog.qmul.ac.uk/victorianlondon/pdf/Registeredfinds.pdf.

Rimmer, J., Connelly, P., Rees Jones, S. and Walker, J. (2011) (eds.) Special collection: poverty in depth: new international perspectives. International Journal of Historical Archaeology 15: 533-636.

Ross, E. (1983). Survival networks: women's neighbourhood sharing in London before World War I. History Workshop Journal 15: 4-27.

Ross, E. (1993). Love and Toil: Motherhood in Outcast London, 1870-1918, Oxford University Press, Oxford.

Rudolph, W. (1985). Sailor Souvenirs: Stoneware Faiences and Porcelain of Three Centuries, Edition Leipzig, Leipzig.

Schneer, J. (1999). London 1900: The Imperial Metropolis, Yale University Press, London.

Seed, J. (2006). "Limehouse blues": looking for Chinatown in London's docks, 1900-40. History Workshop Journal 62: 58-85.

Sheller, M., and Urry, J. (2006). The new mobilities paradigm. Environment \& Planning A 38: 207-226.

Spencer-Wood, S. M. (2004). What difference does feminist theory make in researching households? In Barile, K., and Brandon, J. (eds.), Household Chores and Household Choices, Alabama Press, Tuscaloosa, pp. 235-253.

Spencer-Wood, S. M., and Matthews, C. N. (2011). Impoverishment, criminalization, and the culture of poverty. Historical Archaeology 45(3): 1-10.

Stedman Jones, G. S. (1971). Outcast London: A Study in the Relationships between Classes in Victorian Society, Penguin, Harmondsworth.

Strasser, S. (1999). Waste and Want: A Social History of Trash, Henry Holt, New York.

Styles, J. (2006). Lodging at the Old Bailey: lodgings and their furnishing in eighteenth-century London. In Styles, J., and Vickery, A. (eds.), Gender, Taste and Material Culture in Britain and North America, 1700-1830, Yale University Press, London, pp. 66-80.

Sussman, L. (1997). Mocha, Banded, Cat's Eye and other Factory-Made Slipware. Studies in North East Historical Archaeology, No. 1, Council for North East Historical Archaeology, Boston.

Symonds, J. (2011a). Poverty and progress in the age of improvement: evidence from the Isle of South Uist in the Outer Hebrides. Historical Archaeology 45(3): 106-120.

Symonds, J. (2011b). The poverty trap: or, why poverty is not about the individual. International Journal of Historical Archaeology 15: 563-571.

Symonds, J., Ylimaunu, T. and Nurmi, R. (2009). Pottery dogs and gossip mirrors: engendering household spaces in early modern Finland. Paper presented to the Modern Materials: the Archaeology of Things from the Early Modern, Modern and Contemporary World, CHAT Conference, Keble College, Oxford, 16-18 October.

Tebbutt, M. (1984). Making Ends Meet: Pawnbroking and Working-Class Credit. Methuen London. 
Visram, R. (1986). Ayahs, Lascars and Princes: The Story of Indians in Britain, 1700-1947, Pluto, London. Wall, D. (2009). The language of plates. Paper presented to the Poverty In-Depth: New International Perspectives Symposium, York Archaeological Trust, July, 2-4.

Webster, J. (1999). Resisting traditions: ceramics, identity and consumer choice in the Outer Hebrides from 1800 to the present. International Journal of Historical Archaeology 3: 53-73.

Yamin, R. (2001a). Introduction: becoming New York: the Five Points neighbourhood. Historical Archaeology 35: 1-5.

Yamin, R. (2001b) (ed.) Becoming New York: The Five Points Neighbourhood. Historical Archaeology 35 (3): $1-135$.

Yamin, R. (2001c). Alternative narratives: respectability at New York's Five Points. In Mayne, A., and Murray, T. (eds.), The Archaeology of Urban Landscapes: Explorations in Slumland, Cambridge University Press, Cambridge, pp. 154-170.

Yamin, R. (ed.) (2002). Tales of Five Points: Working Class Life in Nineteenth-Century New York. General Services Administration, Washington. 